\title{
Insider Ownership and Corporate Performance: Evidence from the Adjustment Cost Approach"
}

\author{
W.K. Adrian Cheung \\ Department of Accounting, Finance and Economics \\ Griffith University \\ Email: a.cheung@griffith.edu.au \\ K.C. John Wei \\ Department of Finance \\ Hong Kong University of Science and Technology \\ Email: johnwei@ust.hk
}

\begin{abstract}
* We are grateful to Jun Cai, Kevin Chen, Joseph Fan, Jie Gan, Jiang Luo, and seminar participants at the Hong Kong University of Science and Technology for their helpful comments and suggestions. The authors also wish to thank Jeffry M. Netter (the editor) and an anonymous referee for insightful comments and suggestions, Dr. Virginia Unkefer for editorial assistance and Edmond Leung for research assistance. We especially thank Vidhan Goyal for his insightful suggestions. This paper received financial support from the Center for Asian Financial Markets, Department of Finance, Hong Kong University of Science and Technology. Adrian Cheung acknowledges financial support from the Department of Accounting, Finance and Economics, Griffith University. John Wei acknowledges the financial support from the RGC Research Infrastructure Grant of Hong Kong Special Administration Region, China (RI/93/94.BM02). All errors remain ours.
\end{abstract}

Corresponding author: K.C. John Wei, Department of Finance, Hong Kong University of Science and Technology, Clear Water Bay, Kowloon, Hong Kong; Email: johnwei@ust.hk; Tel: (852)-2358-7676; Fax: (852)-2358-1749. 


\title{
Insider Ownership and Corporate Performance: Evidence from the Adjustment Cost Approach
}

\begin{abstract}
This paper examines the relation between insider ownership and corporate performance in the presence of adjustment costs and investigates how the adjustment costs are determined. In a model specification without adjustment costs, we find that insider ownership is significantly positively associated with corporate performance. But once we allow for adjustment costs, the relationship no longer exists. We find that insider ownership and corporate performance can be explained by their respective lagged values and that many firm characteristics that were previously useful in explaining these two variables turn out to be statistically insignificant. In addition, there is no evidence that insider ownership and corporate performance affect each other. This is consistent with the adjustment cost argument. It is also consistent with the “endogeneity” argument suggested by Demsetz (1983), Demsetz and Lehn (1985), and Demsetz and Villalonga (2001). Finally, we document that the speed of adjustment of insider ownership is positively related to insiders' market timing but negatively to the number of insiders and that the speed of adjustment of Tobin's Q is positively associated with financial leverage and stock price volatility.
\end{abstract}

JEL classification: C23; G30

Keywords: Insider ownership; Corporate performance; Tobin’s Q; Adjustment costs; SystemGMM

\section{JEL classification: C23; G30}

Keywords: Insider ownership; Corporate performance; Tobin’s Q; Adjustment costs; SystemGMM 


\section{Introduction}

The relation between insider ownership and firm performance continues to be an important and contested area of empirical and theoretical research in corporate finance. Demsetz (1983) argues that an ownership structure should arise endogenously and that there should be no systematic relation between insider ownership and firm performance. Demsetz and Lehn (1985) provide evidence of the endogeneity of the ownership structure. Subsequent research that ignores the endogeneity issue finds a nonlinear relation between performance measures and insider ownership (see, for example, Morck, Shleifer, and Vishny (1988)). Demsetz and Villalonga (2001) recently examined different dimensions of ownership and found that, in a regression framework where ownership is treated as an endogenous variable, no relation exists between insider ownership and firm performance. ${ }^{1}$ The issue is far from settled, however. In addition to endogeneity, another important issue that plagues these studies is that the empirical results can be interpreted as either equilibrium or out-of-equilibrium phenomena., ${ }^{2,3}$ Core, Guay and Larcker (2003) note that these two interpretations rest on different assumptions about the nature of adjustment costs in correcting suboptimal contracts. Traditional agency theory assumes that firms can continuously recontract, because there is no adjustment cost. In contrast, Demsetz (1983) assumes that because the adjustment costs are so large, firms cannot recontract even when incentives are not properly aligned.

The existing literature cannot distinguish between optimal (or equilibrium) ownership and observed ownership. The former is what existing theoretical models try to explain, while the latter is what empiricists actually observe. It is possible that optimal ownership and observed

\footnotetext{
${ }^{1}$ Demsetz and Villalonga (2001) also provide an excellent review of post-1985 studies on this issue. See also Davies, Hillier and McColgan (2005) for a recent study using UK data.

${ }^{2}$ See Hermalin and Weisbach (2003). Their comment is made in the context of boards of directors. They also mention that the comment is applicable to other corporate governance mechanisms such as insider ownership.

3 Most studies interpret the estimated relationship as an equilibrium (or static) one.
} 
ownership are different due to the presence of adjustment costs. Himmelberg et al. (1999, p. 383) note that "exploring these costs and how they might change over time for different agency-costreducing mechanisms is a particularly interesting task for future research.”

We take an out-of-equilibrium approach and examine the ownership-performance relationship by explicitly considering adjustment costs. We develop an alternative empirical specification that not only explains the ownership-performance relationship as previous studies did, but also examines how the adjustment costs are determined. This alternative model specification has the following features. First, it explicitly accounts for the possibility that firms may face impediments in moving towards their optimal ownership structure, which may also change over time as the firm's external contracting environment changes. Our model specification represents an empirical extension of existing static models to a dynamic setting. This extension is potentially useful, because if firms adjust to their targeted insider ownership levels gradually over time, many cross-sectional relationships between insider ownership and some previously identified firm characteristics might be spurious. Second, our specification makes use of another advantage of the panel structure of the data that is not fully utilized by existing panel data studies. The advantage allows us to understand the dynamics of the crosssectional relation over time. Third, this approach also permits us to explore the determinants of adjustment costs. Finally, our adjustment cost approach complements the study by Demsetz and Villalonga (2001). While Demsetz and Villalonga consider ownership as a multi-dimensional and also endogenous variable, we consider both ownership and performance as persistent variables.

Using U.S. stock market data and ownership data, we find evidence that supports our major argument. First, in a model specification without adjustment costs, we do find that insider 
ownership is significantly positively associated with corporate performance. Second, once the lagged dependent variables are included in the regressions, the current level of insider ownership (or corporate performance) is affected by its lagged value. In addition, many previously identified explanatory firm characteristics are no longer statistically significant. These findings are consistent with the view that firms adjust their targeted insider ownership level or corporate performance gradually over time due to the presence of adjustment costs. If the effects of lagged dependent variables are ignored, there may be a spurious relationship between these two variables and firm characteristics. Third, we find no evidence that corporate performance and insider ownership affect each other. One may argue that a significant coefficient on lagged insider ownership or corporate performance is also consistent with a model with serially correlated error terms. We analyze this possibility and find that it is not the case.

Overall, our results support the argument that there is no relation between corporate performance and insider ownership once adjustment costs are considered. This finding is consistent with the argument by Demsetz (1983) that there should be no relation between ownership and performance because of endogeneity. Our results are robust to the sampling method, the time period, and the functional form of the model specifications.

Further analysis reveals that the speed of adjustment of insider ownership is positively associated with insiders' market timing but negatively with the number of insiders. The evidence on insiders' market timing conforms to the findings by Seyhun (1992) and Rozeff and Zaman (1998) that insiders adjust their shareholdings faster when stock price movements are greater. The result on the number of insiders is inconsistent with the prediction of Urosevic's (2001) model, which assumes that diversification is the only motive for changes in insider ownership. However, it is consistent with our argument that when insiders have different motives for trades, 
their buy and sell trades may cancel out each other. We also find that the speed of adjustment of Tobin’s Q is positively related to financial leverage and stock price volatility.

The remainder of this paper is organized as follows. Section 2 discusses substantive issues related to ownership-performance dynamics and adjustment costs. Section 3 describes our empirical model and the method used to estimate the model. Section 4 discusses the data and key variables. Section 5 presents summary statistics and empirical results, while Section 6 reports on robustness checks. Section 7 reports the analysis on the determinants of the speed of adjustment of insider ownership and of corporate performance. Finally, Section 8 concludes the paper.

\section{The dynamics of the ownership-performance relationship and adjustment costs}

\subsection{Persistence in insider ownership}

It is important to understand how ownership adjustment costs affect the relation between ownership and performance. In the presence of costly ownership adjustment, insiders will change their ownership only occasionally. Thus, actual ownership levels may deviate from optimal levels for considerable periods of time. Some of the impediments to quick adjustment to ownership levels are as follows:

(1) Legal restrictions on insider trading. Insiders are prohibited from trading on material and nonpublic information. Section 10(b) and Section 16(b) of the Securities Exchange Act of 1934 require that insiders refrain from trading on insider information or to disclose their trades and to disgorge any profit from these trades within six months. These legal requirements increase the cost of transactions and create a legal risk that insiders may face whenever they trade their firm's securities, making them reluctant to trade. That is, legal restrictions on insider trading reduce the speed at which insider ownership adjusts to an optimal level. 
(2) Corporate restrictions on insider trading. Bettis, Cores and Lemmon (2000) find that corporate policies on insider trading are more restrictive than are the legal requirements. These policies typically ban insiders from trading within a certain period of time before or after earnings announcements and other major events. These restrictions are expected to slow down the speed at which insider ownership adjusts.

(3) Short selling constraint. Section 16(c) of the Securities Exchange Act makes it illegal for insiders to sell their firm's stocks short. This makes insiders' selling decisions difficult, as they must establish that they have already owned the stock before they can sell it.

(4) Information asymmetry. Aboody and Lev (2000) show that whenever the information asymmetry between investors and the firm is large, the gains to insider trading are likely to be great. If the firm is engaged in activities in which the information asymmetry problem is severe, insiders are more willing to trade because of potential gains. Thus, the speed of adjustment of insider ownership is expected to be high for firms with high information asymmetry.

(5) Number of insiders. Urosevic (2001) develops a dynamic insider ownership model in which ownership changes are caused by diversification motives only. The model predicts that the speed of adjustment of insider ownership is a positive function of the number of insiders. However, if ownership changes are caused by motives other than diversification, the positive relationship may not hold. In particular, when insiders have different motives for trades, their buy and sell trades may cancel out each other, which causes the speed of adjustment of insider ownership to be negatively associated with the number of insiders.

(6) Insiders' market timing. Consistent with the idea that insiders trade in anticipation of subsequent price reversals, Seyhun (1992) finds that insiders are likely to increase (decrease) their shareholdings following periods of significant price depreciation (appreciation). Rozeff and 
Zaman (1998) also find evidence that insiders are contrarian traders who trade against the market's overreaction to past performance. This suggests that insiders are likely to change their shareholdings during significant price movements and the rate of change is likely to be greater if the price movements are large.

(7) The amenity potential of a firm's outputs. Demsetz and Lehn (1985) suggest that certain industries, such as the media industry, may offer greater amenity potential to investors. Investors are reluctant to sell their shares in these industries. The speed of adjustment is expected to be low in such industries.

\subsection{Persistence in performance}

In general, firms that are less sensitive to market competition or economic conditions should be slower in adjusting their performance to market conditions. Along this line of reasoning, several researchers have analyzed the determinants of the speed of adjustment of firm performance, even though their focus has been on profitability, not on Tobin’s Q. ${ }^{4}$

(1) Sunk costs. Evidence indicates that the greater the sunk costs, the more the persistence of the speed of adjustment of corporate performance. Waring (1996) uses R\&D intensity and advertising intensity to represent sunk costs.

(2) Pricing power. It is expected that the greater the pricing or monopolistic power, the slower the speed of adjustment of corporate performance. Profitability (Mueller (1977)), sales growth (Waring (1996)) and market share (Jacobsen (1988)) have been used to measure pricing power. One expects that firms with greater pricing power are more profitable and have higher sales growth and larger market share. This suggests that the speed of adjustment of corporate performance would be lower for firms with greater pricing power.

\footnotetext{
${ }^{4}$ We thank an anonymous referee for suggesting this literature. Mueller (1977) is the first to examine the persistence of profits at the firm level. See also Jacobsen (1988), Waring (1996), and Villalonga (2004).
} 
(3) Resource intangibility. Villalonga (2004) argues that a firm's endowment of intangible resources is the key to sustainability of profit and shows that resource intangibility is positively related to profit persistence. This suggests that the speed at which corporate performance adjusts is negatively associated with resource intangibility.

(4) Financial leverage. Financial economics shows that financial leverage will increase the volatility of corporate performance, implying that the speed at which firm performance adjusts should be faster for firms with higher financial leverage.

(5) Stock price volatility. If the stock market is efficient, stock prices should reflect a firm's fundamentals. If a firm's fundamentals are more volatile, its stock prices should be also more volatile. This means that stock price volatility should reflect the volatility of firm performance. As a result, one would expect the speed at which firm performance adjusts to be faster for firms with more volatile stock prices.

\section{An empirical framework}

\subsection{A dynamic specification}

Our model specification is as follows:

$$
\begin{aligned}
& y_{i t}^{*}=\phi x_{i t}+A C_{i t}+u_{i}+\eta_{i t}, \\
& y_{i t}-y_{i t-1}=\lambda\left(y_{i t}^{*}-y_{i t-1}\right)+e_{i t},
\end{aligned}
$$

where $y_{i t}^{*}$ and $y_{i t}$ are optimal insider ownership and actual insider ownership, respectively. The variable $x_{i t}$ is corporate performance; ${ }^{5} \boldsymbol{C}_{i t}$ is a vector of observable exogenous or control variables proposed by principal-agent models, which are discussed below; $\phi$ and $\boldsymbol{A}$ are regression coefficients; $u_{i}$ is the firm-specific (or fixed) effect; and $\eta_{i t}$ and $e_{i t}$ are white-noise error terms.

\footnotetext{
${ }^{5}$ We also estimate another equation in which Tobin's Q is the dependent variable and insider ownership is one of the explanatory variables.
} 
We assume that $\mathrm{E}\left(\eta_{i t} e_{i t}\right)=0$ and $\mathrm{E}\left(\eta_{i t}\right)=\mathrm{E}\left(e_{i t}\right)=0$. The index subscripts, $i$ and $\mathrm{t}$, denote crosssectional units and time periods, respectively.

Equation (1a) is a standard regression equation commonly used in the literature. It describes how optimal ownership is determined by corporate performance and a set of factors proposed by principal-agent theory. Equation (1b) is the adjustment cost equation, where $\lambda$ refers to the speed of adjustment. This equation explicitly accounts for the fact that firms may face impediments or adjustment costs in moving toward their optimal ownership structure. By inserting equation (1a) into equation (1b) and rearranging for $y_{i t}$, we obtain

$$
y_{i t}=\alpha_{1} x_{i t}+\alpha_{2} C_{i t}+\alpha_{3} y_{i t-1}+\alpha_{4} u_{i}+\varepsilon_{i t}
$$

where $\alpha_{1}=\lambda \phi, \alpha_{2}=\lambda A, \alpha_{3}=1-\lambda, \alpha_{4}=\lambda$, and $\varepsilon_{i t}=\lambda \eta_{i t}+e_{i t}$.

Equation (2) contains a lagged dependent variable whose coefficient is equal to one minus the speed of the adjustment. Ignoring this lagged dependent variable is likely to lead to mis-specification. Equation (2) and equation (1a) are the same only when the insider ownership structure can be adjusted instantaneously, i.e., when $\lambda=1$. Equation (2) also explicitly accounts for adjustment costs. It encompasses other static models and allows us to examine whether the existing models are mis-specified by testing whether $\lambda$ is statistically different from one.

\subsection{Econometric specification and the system-GMM estimation method}

For estimation purposes, we remove $u_{i}$ by taking the first difference of equation (2) to obtain the following equation:

$$
\Delta y_{i t}=\alpha_{0 t}+\alpha_{1} \Delta x_{i t}+\alpha_{2} \Delta C_{i t}+\alpha_{3} \Delta y_{i t-1}+\Delta \omega_{i t}
$$

where $\Delta$ is the first-differencing operator. ${ }^{6}$

\footnotetext{
${ }^{6}$ Note that we add time dummies, $\alpha_{0 \text { t }}$, to control for all shocks that affect all firms in the same way.
} 
Even with the above transformation, estimating the relationship between $\Delta y$ and $\Delta x$ is challenging. Fortunately, a system-GMM (generalized method of moments) can be used to solve this problem. ${ }^{7}$ It is a variant of the GMM estimation method originally proposed by Arellano and Bond (1991) and Arellano and Bover (1995) and subsequently improved by Blundell and Bond (1998). The system-GMM estimator combines the difference equation with a level equation to form a system of equations for estimation purposes. This method is reported to perform well with highly persistent data like insider ownership and corporate performance.

\section{Key variables and data sources}

First, we construct annual time series of insider ownership and corporate performance. We use the logarithm of the percentage of insider ownership (IOWN) and Tobin's q (Q) as the measures for insider ownership and corporate performance, respectively. The percentage of insider ownership is defined as the number of shares owned by insiders divided by the total number of shares outstanding and multiplied by 100. Insiders are managers, senior officers and directors of a firm. Tobin's Q is defined as the ratio of the market value of a firm divided by the replacement value of its assets. For firm value, we follow Himmelberg et al. (1999) and use the market value of common equity (from CRSP) plus the estimated market value of preferred stock (roughly estimated as ten times the preferred dividends) plus the book value of total liabilities. For replacement value of assets, we use the book value of total assets.

To control for known firm characteristics, we use a similar set of exogenous variables as used by Himmelberg et al. (1999). These variables include the logarithm of sales (FSIZE), the

\footnotetext{
${ }^{7}$ It is well known that the standard panel analysis has a serious estimation problem if there are lagged dependent variables in the equations. First, the fixed-effects estimator of the coefficients on endogenous and exogenous lagged variables is biased and inconsistent (Matyas and Sevestre (1996)). Second, the first-differencing transformation in equation (3) induces a first-order moving average process in the error terms, which may be dealt with by the GMM method. But the standard GMM estimator is known to have a large finite sample bias and very low precision in simulation studies (Arellano and Bond (1991)). One of the reasons is that the lagged levels of the dependent variable are only weakly correlated with subsequent first-differencing series and thus provide a weak instrument for firstdifferencing variables. One notable example is when panel data are highly persistent.
} 
ratio of tangible long-term assets to sales (HARD_C), the ratio of operating income to sales (CF), the standard deviation of idiosyncratic stock price risk (MRA), the ratio of research and development expenditures to tangible long-term assets (SOFT_C1), the ratio of advertising expenditures to the stock of long-term assets (SOFT_C2), and the ratio of capital expenditures to long-term assets (GROWTH). Demsetz and Villalonga (2001) also use a similar set of variables.

Information on insider ownership is extracted from Compact Disclosure CDs. ${ }^{8}$ We extract ownership data from the July report for each of the years from 1991 to 2000 and supplement the data by collecting other relevant information directly from CRSP and Compustat. ${ }^{9}$ Only those companies that meet our selection criteria are used in the data analysis. First, we restrict ourselves to firms that have their financial year-end in December each year. This ensures that information extracted from financial statements is available in July each year. Second, we choose those firms that have no missing data (on sales, the book value of total assets, and the stock price as well) over the period 1991 to 2000. Third, in order to derive useful estimates from our model specification, a minimum of four consecutive years of observations is required. This selection process yields a total of 1,430 firms.

In Section 2, we identify seven variables that may be associated with adjustment costs of insider ownership. Since legal restrictions on insider trading and short-selling constraints are the same for all firms during our sample period, we do not include these two variables in our adjustment-speed regressions. We also exclude corporate restrictions on insider trading, since the effect of these policy restrictions can be detected only on particular days. Following Brennan and Subrahmanyam (1995), we use the logarithm of one plus the number of analyst forecasts (NOAF) from $\mathrm{I} / \mathrm{B} / \mathrm{E} / \mathrm{S}$ and the logarithm of the percentage of institutional ownership (INOWN) from

\footnotetext{
${ }^{8}$ Anderson and Lee (1997) report that Compact Disclosure is the most reliable source of ownership data in the U.S.

${ }^{9}$ The July report on the Compact Disclosure CDs contains the most complete data among all months.
} 
Compact Disclosure CDs to proxy for information asymmetry. A high value of NOAF (INOWN) means low (high) information asymmetry. The number of insiders (NHOLDER) is taken from Compact Disclosure CDs. Jalilvand and Harris (1984) define insiders’ market timing as a ratio of a firm's share price in year $t$ to the average of its share price in the two preceding years, denoted as Price_Ratio. However, as discussed in Section 2, the speed of adjustment of insider ownership depends on the magnitude of stock price movements irrespective of direction. As a result, our insiders’ market timing variable (TIMING) is defined as the absolute value of (Price_Ratio - 1). As for the amenity potential of a firm's outputs (AMENITY), we follow Demsetz and Lehn (1985) by defining a dummy variable that is equal to one if the firm is in a media or publishing industry and zero otherwise.

Section 2 suggests five variables that may be associated with the speed of adjustment of firm performance. We use the sum of R\&D intensity (SOFT_C1) and advertising intensity (SOFT_C2) as a proxy for sunk costs (SC). We measure pricing power with three different proxies: profitability, sales growth, and market share. Profitability is measured by return on assets (ROA), which is equal to the ratio of net operating income excluding extraordinary items to total assets. Sales growth (SG) is the growth rate of annual sales. To measure market share (MS), we first extract business segment sales data from the Compustat business information file. Two-digit SIC codes are used to define a business segment. We then compute the ratio of a firm's sales in a business segment to the total sales in that segment and then weigh it by the ratio of the firm's sales in the segment to the total sales of the firm. Following Villalonga (2004), we use Tobin's Q as a measure of resource intangibility. Financial leverage is measured by the ratio of long-term and short-term debt to total assets (DA). The stock price volatility (STDDEV) is the 
standard deviation of daily stock returns for the period covered by the annual sample. For more details on variable definitions, see Appendix A.

\section{Summary statistics and empirical results}

\subsection{Summary statistics}

Our final sample consists of 11,817 firm-year observations. It is unbalanced panel data, where the shortest sequence of observations for a firm is four years and the longest sequence is ten years. The numbers of firms with four to ten consecutive years of observations are 109, 102, 11, 126, 183, 131 and 668, respectively. Around 47\% of the firms have consecutive observations for ten years.

Table 1 presents the descriptive statistics for the key variables. The average value of Tobin's Q is 1.90, while the average value of insider ownership is 5.52 percent (= $\exp (1.7075)$ ), which is converted from the value of 1.7075 reported in the table. The simple correlation between these two variables is -0.17 and is statistically significant at the $1 \%$ level. The simple correlation between the changes in the two variables is +0.007 , which is not significant. This suggests that there is a significant negative correlation between these two variables, but no correlation between their changes. The first-order autocorrelation of insider ownership is 0.784 , which is significant. The first-order autocorrelation of Tobin's Q is 0.903 , which is also significant. Such a high autocorrelation in both variables suggests that they are highly persistent and that they should be modeled as a dynamic and persistent process.

\subsection{Evidence from the static fixed-effects specification}

To facilitate comparisons with previous studies, we estimate a fixed-effects panel regression of equation (1a), where the dependent variable is observed insider ownership or firm performance and the explanatory variables are similar to those used by Himmelberg et al. (1999) 
and Demsetz and Villalonga (2001). Since the fixed-effects model specification is not the focus of this paper, the results are not tabulated but are available upon request. The unreported results indicate that the effects of the set of control variables in our regressions are broadly the same as the fixed-effects model used by Himmelberg et al. (1999). Many control variables can explain the differences in insider ownership and/or in corporate performance. When fixed-effects models are used, whether or not we include the control variables, insider ownership is always significantly positively related to Tobin's Q. In addition, the fixed effects are the major determinant of the changes in insider ownership or in Tobin's Q within firms over time.

\subsection{Evidence from the dynamic model specification}

Table 2 reports the one-step system-GMM estimates for the insider ownership equation. ${ }^{10}$ Row 1 of Panel A in Table 2 shows that the validity of lagged levels dated $t-4$ as instruments in the first-difference equations is not rejected by the Sargan test of over-identification restrictions. The differenced-Sargan statistic (shown in Row 2) that specifically tests the additional moment conditions used in the level equations also accepts that lagged first differences dated $t-3$ are valid instruments in the level equations. Thus, the system-GMM parameter estimates are accepted and presented in Panel B.

Panel B shows that in the ownership regression, the coefficient on Tobin's Q is negative but not statistically significant, implying that the current Tobin's Q does not affect insider ownership. The coefficient on lagged insider ownership (IOWN(-1)) is positive and statistically significant, meaning that any decrease (increase) in insider ownership will cause a further decrease (increase) in subsequent insider ownership. The adjustment speed is 0.4177 (= $1-$ 0.5823), which is equivalent to a Koyck duration interval of 3.43 with $p=95 \%$, where $p$ is the

\footnotetext{
${ }^{10}$ Blundell and Bond (1998) suggest that the asymptotic inference based on the one-step system-GMM estimator may be more reliable than that based on the two-step estimator even in moderately large samples.
} 
percentage of the decay. ${ }^{11}$ This means that it takes 3.43 years to complete a $95 \%$ adjustment, suggesting that the adjustment cost is considerably high. Finally, except for firm size and its square, none of the control variables is statistically significant in the ownership equation. This finding is consistent with the view that a spurious relationship may be produced between insider ownership and other known firm characteristics, if firms adjust to their targeted insider ownership gradually over time.

In Table 3, we find similar results for the Tobin's Q equation. The coefficients on IOWN and IOWN² are not statistically significant, suggesting that insider ownership does not affect Tobin's Q. The coefficient on lagged Tobin’s Q is 0.843 , implying an adjustment speed of 0.157 $(=1-0.8430)$, which is equivalent to a Koyck duration interval of 1.62 . In other words, it takes about 1.62 years to complete a 95\% adjustment for firm performance, which is much faster than the adjustment for insider ownership. Note that none of the control variables is statistically significant at the $5 \%$ level.

The above results hinge upon the assumption that there are no serial correlations in the error terms. This assumption is essential for the consistency of GMM estimators. Rows 3 and 4 of Panel A in Tables 3 and 4 report tests for the absence of the first-order and the second-order serial correlations in the first-differenced residuals in equation (4), respectively. If the error terms are not serially correlated, the first-differenced residuals should be negatively autocorrelated in the first order but not in the second order. Results in both rows of Panel A in both Tables confirm that there is no evidence of serial correlations in the error terms.

The results in both Tables 3 and 4 show that insider ownership and corporate performance are not related to each other in the presence of adjustment costs. This evidence is

\footnotetext{
${ }^{11}$ The Koyck duration interval measures the time lag between a change in insider ownership and the moment that $p$ percent of its effect has decayed. The Koyck duration is computed as $\ln (1-p) / \ln (\lambda)$, where $p$ is the percentage of the decay and $\lambda$ is the speed of adjustment. See Koyck (1954) and Clarke (1976) for details.
} 
consistent with the “endogeneity” argument by Demsetz (1983), Demsetz and Lehn (1985), and Demsetz and Villalonga (2001).

\section{Robustness checks}

\subsection{A competing model}

One can find that a fixed-effects model with serially correlated errors is a competing model to our new model specification. The competing model can be represented as follows:

$$
\begin{aligned}
& y_{i t}=\phi x_{i t}+A C_{i t}+u_{i}+\eta_{i t}, \\
& \eta_{i t}=\rho \eta_{i t-1}+e_{i t} .
\end{aligned}
$$

The first equation is exactly the same as equation (1a), while the second equation assumes that the error term in equation (1a) follows a moving average of a first-order process. Rearranging the first equation for $\eta_{i t}$ and substituting it into the second equation, we obtain

$$
y_{i t}=\gamma_{1} y_{i t-1}+\gamma_{2} x_{i t}+\gamma_{3} x_{i t-1}+\gamma_{4} \mathbf{C}_{i t}+\gamma_{5} \mathbf{C}_{i t-1}+\gamma_{6} u_{i}+e_{i t}
$$

where $\gamma_{1}$ is equal to $\rho, \gamma_{2}$ measures $\phi, \gamma_{3}$ is $-\rho \phi, \gamma_{4}$ represents a vector of coefficients called $\boldsymbol{A}, \gamma_{5}$ is $-\rho \mathbf{A}$ and $\gamma_{6}$ is simply $1-\rho .^{12}$ This specification suggests that the source of statistical significance is due to the presence of serial correlation but not to the presence of adjustment costs. To determine if equation (2) prevails over equation (5), we can simply look at the statistical significance of the coefficients $\gamma_{3}$ and $\gamma_{5}$, since equation (5) nests equation (2). Our test is based on the differenced-Sargan (dS) test that examines whether the inclusion of one or more variables can make a significant difference. ${ }^{13}$

Row 5 of Panel A in Table 2 provides the estimation results for insider ownership, while

\footnotetext{
${ }^{12}$ Equation (5) is remarkably close to our new model specification in equation (2). The only difference is that two additional new terms, namely, lagged $x$ and $\boldsymbol{C}$, are now added to equation (5). Note that a nonzero $\rho$ also implies nonzero $\gamma_{1}, \gamma_{3}$ and $\gamma_{5}$. In other words, the presence of serial correlation in the error terms also gives rise to the spurious relationship between the current y and the lagged y.

${ }^{13}$ Arellano and Bond (1991) show that the dS test follows a Chi-square distribution with $k$ degrees of freedom, where $k$ is the difference between the degrees of freedom under the restricted model (equation (2)) and the unrestricted model (equation (5)). Bond and Windmeijer (2002) recommend the use of the dS test for model identification purposes. For additional information about the dS test, see Bond and Windmeijer (2002).
} 
Row 5 of Panel A in Table 3 shows the results for Tobin's Q. In either case, the dS test (for model comparison) is not statistically significant at the $5 \%$ level, suggesting that $\gamma_{3}$ and $\gamma_{5}$ are all jointly equal to zero. In other words, the significance of the adjustment coefficients is not due to serial correlations, suggesting that the adjustment cost model is a better model.

\subsection{Results from other robustness checks}

We also investigate whether our results are sensitive to the sample period, the functional form of model specifications, and an alternative measure of insider ownership. The issue of measurement errors, the choice of instruments, and the simultaneity issue between ownership and performance are also dealt with. To save space, these results are not tabulated but are available upon request. Taken together, our results that the dependent variable is related to its lagged value are quite robust. They are not sensitive to the functional form of model specifications, the sampling method, the time period, or the measure of insider ownership. In addition, our estimates are derived from instruments that are not sensitive to measurement error problems in Tobin's Q and insider ownership. ${ }^{14}$

\section{Analysis on determinants of the speed of adjustment}

One may argue that our new model specification in equation (2) is restrictive. In general, we expect that the coefficient on the lagged dependent variable is firm specific. That is,

$$
y_{i t}=\alpha_{1} x_{i t}+\alpha_{2} C_{i t}+\alpha_{3 i} y_{i t-1}+\alpha_{4} u_{i}+\omega_{i t} .
$$

If this were the case, we may reinterpret the aforementioned evidence as the average case of equation (6). By incorporating the possible determinants of the adjustment coefficient for insider ownership discussed in Sections 2 and 4, we can express $\alpha_{3 i}$ as

\footnotetext{
${ }^{14}$ In particular, if more than one legitimate instrument is available, only the instruments dated earlier are selected. These instruments are far from current observations and are expected to show little correlation with current measurement errors.
} 


$$
\begin{aligned}
\alpha_{3 i} & =1-\lambda_{i}=1-\left(\beta_{0}+\beta_{1} \text { AMENITY }_{i t}+\beta_{2} \text { INOWN }_{i t}++\beta_{3} \text { NHOLDER }_{i t}+\beta_{4} N O A F_{i t}+\beta_{5} \text { TIMING }_{i t}\right) \\
& =\gamma_{0}+\gamma_{1} \text { AMENITY }_{i t}+\gamma_{2} \text { INOWN }_{i t}+\gamma_{3} N H O L D E R_{i t}+\gamma_{4} N O A F_{i t}+\gamma_{5} \text { TIMING }_{i t}=\gamma \mathbf{D}_{i t},
\end{aligned}
$$

where $\gamma_{0}=1-\beta_{0}$, and $\gamma_{k}=-\beta_{k}, k=1, \ldots, 5$. The intercept term $\left(\beta_{0}\right)$ is included to capture other effects, such as legal restrictions on insider trading (or short sales). By substituting the above restriction into equation (6), we obtain a similar equation, where additional interaction terms between lagged $y$ and $D_{i t}$ (labeled as $y_{i t-1} \times D_{i t}$ ) are added. From our discussions in Sections 2 and 4, we expect that $\gamma_{1}>0, \gamma_{2}<0, \gamma_{4}>0, \gamma_{5}<0$, and that $\gamma_{3}$ is indeterminate.

Table 4 presents the estimation results. The results show that TIMING has a negative relationship with the autoregressive coefficient on insider ownership $\left(\gamma_{5}=-0.0433\right)$ at the $1 \%$ significance level, while NHOLDER is positively related to the autoregressive coefficient $\left(\gamma_{3}=0.0010\right) .{ }^{15}$ The results suggest that the speed of adjustment for insider ownership is quicker in firms with significant price movements (TIMING) or with fewer insiders (NHOLDER). The evidence on TIMING confirms the findings by Seyhun (1992) and Rozeff and Zaman (1998). The result on the number of insiders is inconsistent with the predication of Urosevic's (2001) model that assumes diversification as the only motive for changes in insider ownership. The result is however consistent with the argument that different motives for trades among insiders, which can cancel out each other, may slow the speed of adjustment of insider ownership.

As discussed in Section 2, the speed of adjustment of firm performance is related to another set of variables. They are SC (sunk cost), ROA (return on total assets), SG (sales growth), MS (market share), Q (resource intangibility), DA (degree of financial leverage) and STDDEV (standard deviation of stock returns). That is,

\footnotetext{
${ }^{15}$ To reduce the impact of the multicollinearity problem, only INOWN is used as a proxy for information asymmetry. The result is very much the same if NOAF is used.
} 


$$
\begin{aligned}
\alpha_{3 i} & =1-\lambda_{i}=1-\left(\beta_{0}+\beta_{1} D A_{i t}+\beta_{2} M S_{i t}+\beta_{3} Q_{i t}+\beta_{4} R O A_{i t}+\beta_{5} S C_{i t}+\beta_{6} S G_{i t}+\beta_{7} S T D D E V_{i t}\right) \\
& =\gamma_{0}+\gamma_{1} D A_{i t}+\gamma_{2} M S_{i t}+\gamma_{3} Q_{i t}+\gamma_{4} R O A_{i t}+\gamma_{5} S C_{i t}+\gamma_{6} S G_{i t}+\gamma_{7} S T D D E V_{i t}=\gamma \mathbf{D}_{i t} .
\end{aligned}
$$

From discussions in Sections 2 and 4, we expect that $\gamma_{1}<0, \gamma_{2}>0, \gamma_{3}>0, \gamma_{4}>0, \gamma_{5}>0, \gamma_{6}$ $>0$, and $\gamma_{7}<0$. The results are reported in Table 5, where market share (MS) is used as a proxy for pricing power (the results are similar if SG or ROA is used). The results show that financial leverage (DA) and stock price volatility (STDDEV) are both significantly negatively associated with Tobin's $Q\left(\gamma_{1}=-0.1358\right.$ with $p=0.000$ and $\gamma_{7}=-0.0671$ with $p=0.072$, respectively). The evidence suggests that the impact of financial leverage and stock price volatility on the speed of adjustment of Tobin's Q is significantly positive. The results are consistent with the argument that firms with higher financial leverage and more volatile stock prices tend to have less stable corporate performance.

\section{Conclusions}

Several main findings emerge from our analysis on the relationship between insider ownership and corporate performance. First, the lagged dependent variable is important in explaining the current dependent variable, regardless of whether the dependent variable is insider ownership or Tobin's Q. The evidence suggests that insider ownership and Tobin's Q are both highly persistent over time and that the presence of adjustment costs is important in their dynamic relationship. Second, once we incorporate the lagged dependent variable into the model, many firm characteristics that were previously found useful in explaining insider ownership become insignificant. The findings are consistent with our argument that ignoring adjustment costs would produce a spurious relationship between insider ownership/firm performance and firm characteristics. Third, consistent with Demsetz (1983), Demsetz and Lehn (1985), and Demsetz and Villalonga (2001), we find no evidence that there is a relationship between corporate performance and insider ownership. Our main findings are robust to the sample period, 
the sampling method, an alternative measure of insider ownership, and the functional form of model specifications. We also consider whether the data support a competing model with serially correlated error terms instead of adjustment costs. The evidence supports our adjustment cost model for both insider ownership and Tobin’s Q.

Further analysis reveals that the speed of adjustment of insider ownership is positively associated with insiders' market timing but negatively with the number of insiders. The former evidence is consistent with the timing ability of insiders documented by Seyhun (1992), and Rozeff and Zaman (1998). The latter evidence is inconsistent with the prediction of Urosevic's (2001) theoretical model that assumes that diversification is the only motive for changes in insider ownership, but it is consistent with the argument that when insiders have different motives for trades, their buy and sell trades may cancel out each other, which may lower the speed of adjustment of insider ownership. Finally, we find that the speed of adjustment of Tobin's Q is positively related to financial leverage and stock price volatility. The results are consistent with theoretical arguments that firms with higher leverage and more volatile stock prices tend to have less stable corporate performance.

The relation between insider ownership and corporate performance continues to be debated from both theoretical and empirical points of view. Our paper contributes to this relatively controversial issue by providing additional evidence with an out-of-equilibrium (or adjustment-cost) approach. Our analysis on the ownership or performance dynamics is exploratory. Additional theoretical and empirical research is needed to understand how the dynamics should be determined.

Our findings have implications for studies that examine the relation between other 
aspects of corporate governance and firm performance. ${ }^{16}$ In a recent paper, Gillan (2006) provides an excellent summary of the corporate governance literature. This review demonstrates that many other dimensions of corporate governance may affect firm performance differently. For example, several recent papers examine the effect of board size and structure on firm performance and find conflicting evidence. It is possible that a statistically significant relation between board size/structure or other aspects of corporate governance and firm performance may not actually exist when the persistent nature of these corporate governance variables is considered. ${ }^{17}$ Such analysis is left for future research.

\footnotetext{
${ }^{16}$ Insider ownership is of course one such feature of corporate governance.

${ }^{17}$ See, for example, Linck, Netter, and Yang (2005a, 2005b) for the study of board changes over time.
} 


\section{Appendix A}

Definition of variables*

\begin{tabular}{|c|c|}
\hline Acronym & Definition and description \\
\hline \multicolumn{2}{|c|}{ Dependent variables } \\
\hline Q & Tobin's Q is the ratio of the value of the firm divided by the replacement cost of assets. \\
\hline IOWN & $\begin{array}{l}\text { The logarithm of the percentage of total common equity holdings owned by top-level } \\
\text { managers as a fraction of common equity outstanding. }\end{array}$ \\
\hline \multicolumn{2}{|c|}{ Determinants of the speed of adjustment of insider ownership } \\
\hline AMENITY & $\begin{array}{l}\text { A dummy variable, which is equal to } 1 \text { if the firm is a newspaper publisher, book publisher, } \\
\text { magazine publisher, or broadcaster; zero otherwise. }\end{array}$ \\
\hline INOWN & $\begin{array}{l}\text { The logarithm of the percentage of total common equity holdings held by institutional } \\
\text { investors as a fraction of common equity outstanding. }\end{array}$ \\
\hline NHOLDER & The number of insiders in the firm. \\
\hline NOAF & $\begin{array}{l}\text { The logarithm of one plus the number of analyst forecasts, taken from } \mathrm{I} / \mathrm{B} / \mathrm{E} / \mathrm{S} \text {. It is used to } \\
\text { proxy for information asymmetry }\end{array}$ \\
\hline TIMING & $\begin{array}{l}\text { The absolute percentage change of stock price in year t relative to the average stock price in } \\
\text { the two preceding years. In each year, the stock price is calculated as the average of the high } \\
\text { and low levels of the stock price during the year. It is used to proxy for insiders' market } \\
\text { timing. }\end{array}$ \\
\hline
\end{tabular}

Determinants of the speed of adjustment of Tobin's $Q$

DA The ratio of long-term and short-term debt to total assets, used to proxy for the degree of financial leverage.

MS A weighted average of a firm's sales in a business segment to the total sales in the same business segment, used to proxy for market share. The weights are the ratio of the firm's segment sales to its total sales. It is used to proxy for pricing power.

ROA The ratio of EBIT to total assets, used to proxy for profitability and pricing power.

SC The sum of SOFT_C1 and SOFT_C2, used to proxy for sunk cost.

SG The percentage change of annual sales, used to proxy for pricing power.

STDDEV The standard deviation of daily stock returns, used to proxy for stock price volatility.

Control variables

$\mathrm{CF}$

The ratio of operating income to sales, used to proxy for market power or agency costs and to measure the gross cash flows available for operations.

FSIZE The natural logarithm of sales, used to measure firm size.

GROWTH The ratio of capital expenditures to the stock of property, plant and equipment.

HARD_C The ratio of tangible, long-term assets (property, plant, and equipment) to sales, used to measure the alleviation of agency problems due to the fact that such assets are easily monitored and provide good collateral.

MRA The standard deviation of idiosyncratic stock price risk, calculated as the standard error of the residuals from a CAPM model estimated using daily data for the period covered by the annual sample. It is used to proxy for managerial risk aversion.

SOFT_C1 The ratio of research and development expenditures to the stock of property, plant, and equipment, used to measure the role of "R\&D capital” relative to other non-fixed assets.

SOFT_C1_DUM A dummy variable equal to 1 if R\& D data is available, and otherwise equal to zero.

SOFT_C2 The ratio of advertising expenditures to the stock of property, plant, and equipment, used to measure the role of "advertising capital” relative to other non-fixed assets.

SOFT_C2_DUM A dummy variable equal to 1 if SOFT_C2 data is available and otherwise equal to zero.

*Part of this table is extracted from Himmelberg et al. (1999), Table 2, page 367. 


\section{References}

Aboody, D., Lev, B., 2000. Information asymmetry, R\&D and insider gains. Journal of Finance $55,2747-2766$.

Anderson, R., Lee, S., 1997. Ownership studies: the source does matter. Journal of Financial and Quantitative Analysis 32, 311-329.

Arellano, M., Bond, S., 1991. Some tests of specification for panel data: Monte Carlo evidence and an application to employment equations. Review of Economic Studies 58, 277-297.

Arellano, M., Bond, S., 1998. Dynamic panel data estimation using DPD98 for GAUSS: a guide for the users. Unpublished working paper, available at http://www.ifs.org.uk/staff/steve_b.shtml.

Arellano, M., Bover, O., 1995. Another look at the instrumental variable estimation of errorcomponents models. Journal of Econometrics 68, 29-51.

Bettis, J., Coles, J., Lemmon, M., 2000. Corporate policies restricting trading by insiders. Journal of Financial Economics 57, 191-220.

Blundell, R., Bond, S., 1998. Initial conditions and moment restrictions in dynamic panel data models. Journal of Econometrics 87, 115-143.

Bond, S., Windmeijer, F., 2002. Finite sample inference for GMM estimators in linear panel data models. Cemmap working paper 04/02, The Institute for Fiscal Studies and Department of Economics, University College, London.

Brennan, M.J., Subrahmanyam, A., 1995. Investment analysis and price formation in securities markets. Journal of Financial Economics 38, 361-381.

Clarke, D.G. 1976. Econometric measurement of the duration of advertising effect on sales. Journal of Marketing Research 13, 345-357.

Core, J., Guay, W., Larcker, F., 2003. Executive equity compensation and incentives: a survey. Economic Policy Review 9, 27-50.

Davis, J., Hillier, D., McColgan, P., 2005. Ownership structure, managerial behavior and corporate value. Journal of Corporate Finance 11, 645-660.

Demsetz, H. 1983. The structure of ownership and the theory of the firm. Journal of Law and Economics 26, 375-390.

Demsetz, H., Lehn, K., 1985. The structure of corporate ownership: causes and consequences. Journal of Political Economy 93, 1155-1177.

Demsetz, H., Villalonga, B., 2001. The ownership structure and corporate performance. Journal 
of Corporate Finance 7, 209-233.

Gillan, S., 2006. On corporate governance: an overview and introduction to the special issue. Journal of Corporate Finance, forthcoming.

Hermalin, B., Weisbach, M., 2003. Boards of directors as an endogenously determined institution: a survey of the economic literature. Economic Policy Review 9, 1-20.

Himmelberg, C., Hubbard, G., Palia, D., 1999. Understanding the determinants of managerial ownership and the link between ownership and performance. Journal of Financial Economics 53, 353-384.

Jacobsen, R., 1988. The persistence of abnormal returns. Strategic Management Journal 9, 415430.

Jalilvand, A., Harris, R., 1984. Corporate behavior in adjusting to capital structure and dividend targets: an econometric study. Journal of Finance 39, 127-144.

Koyck, L.M. 1954. Distributed lags and investment analysis. Amsterdam: North-Holland.

Linck, J.S., Netter, J., Yang, T., 2005a. The determinants of board structure. Working paper, University of Georgia.

Linck, J.S., Netter, J., Yang, T., 2005b. Effects and unintended consequences of the Sarbanes Oxley act on corporate boards. Working paper, University of Georgia.

Matyas, L., Sevestre, P., 1996. The Econometrics of Panel Data: A Handbook of the Theory with Applications. $2^{\text {nd }}$ revised edition, Kluswer Academic Publishers, Netherlands.

Morck, R., Shleifer, A., Vishny, R., 1988. Management ownership and market valuation: an empirical analysis. Journal of Financial Economics 20, 293-315.

Mueller, D.C., 1977. The persistence of profits above the norm. Economica 44, 369-380.

Rozeff, M., Zaman, M., 1998. Overreaction and insider trading: evidence from growth and value portfolios. Journal of Finance 53, 701-716.

Seyhun, H.N., 1992. Why does aggregate insider trading predict future stock returns? Quarterly Journal of Economics 107, 1303-1331.

Urosevic, B., 2001. Dynamics of corporate insider ownership: theory and evidence. Working paper, Haas School of Business, University of California at Berkeley.

Villalonga, B., 2004. Intangible resources, Tobin's q, and sustainability of performance differences. Journal of Economic Behavior and Organization 54, 205-230.

Waring, G.F., 1996. Industry differences in the persistence of firm-specific returns. American Economic Review 86, 1253-1265. 
Table 1

Summary statistics of key variables

The sample has 11,817 firm-year observations during 1991-2000. Insider ownership (IOWN) is the log of the number of shares owned by insiders (directors and officers) divided by the total number of shares outstanding. Tobin's Q (Q) is defined as the ratio of the market value of a firm divided by the replacement value of its assets. Firm value is the market value of common equity plus the estimated market value of preferred stock (roughly estimated as ten times the preferred dividends) plus the book value of total liabilities; replacement value of assets is the book value of total assets. AMENITY, INOWN, NHOLDER, NOAF, and TIMING and the five potential determinants of the speed of adjustment of insider ownership. DA, MS, Q, ROA, SC, SG, and STDDEV are the seven potential determinants of the speed of adjustment of Tobin's Q. Following Himmelberg et al. (1999) we include CF, FSIZE, GROWTH, HARD_C, MRA, SOFT_C1, and SOFT_C2 as our control variables. The definition of these variables is described in Appendix A.

\begin{tabular}{|c|c|c|c|c|}
\hline Variables & Average & Standard deviation & Skewness & Kurtosis \\
\hline \multicolumn{5}{|c|}{ Dependent variables } \\
\hline $\mathrm{Q}$ & 1.9022 & 3.7521 & 1.4834 & 0.2044 \\
\hline IOWN & 1.7075 & 1.8360 & -0.5541 & -0.3389 \\
\hline \multicolumn{5}{|c|}{ Determinants of the speed of adjustment of insider ownership } \\
\hline AMENITY & 0.0159 & 0.1251 & 7.7387 & 57.8976 \\
\hline INOWN & 2.9920 & 1.4518 & -1.6418 & 2.1078 \\
\hline NHOLDER & 13.6930 & 11.1825 & 1.8905 & 6.8772 \\
\hline NOAF & 1.1759 & 1.2208 & 0.3441 & -1.4285 \\
\hline TIMING & 0.8784 & 0.3275 & -2.3079 & 3.3310 \\
\hline \multicolumn{5}{|c|}{ Determinants of the speed of adjustment of Tobin's $Q$} \\
\hline DA & 1.6399 & 0.6181 & -1.8601 & 1.9932 \\
\hline MS & 0.0017 & 0.0089 & 47.1387 & 363.8173 \\
\hline ROA & 1.4310 & 0.8423 & -1.2672 & -0.0939 \\
\hline SC & 1.7264 & 0.2634 & -3.4518 & 14.7213 \\
\hline SG & 0.0729 & 0.4657 & 0.6229 & 185.8539 \\
\hline STDDEV & 0.0345 & 0.0270 & 3.3186 & 20.9820 \\
\hline \multicolumn{5}{|c|}{ Control variables } \\
\hline $\mathrm{CF}$ & 0.7573 & 0.6108 & -2.4677 & 4.1392 \\
\hline FSIZE & 20.7411 & 1.4820 & -13.9223 & 191.9223 \\
\hline GROWTH & 0.9462 & 0.1621 & -5.6089 & 30.8737 \\
\hline HARD_C & 0.9800 & 0.1049 & -8.6925 & 77.8786 \\
\hline MRA & 0.0022 & 0.0111 & 7.4277 & 78.7500 \\
\hline SOFT_C1 & 0.8542 & 0.2231 & -3.2387 & 9.7215 \\
\hline SOFT_C2 & 0.8722 & 0.0992 & -5.7520 & 50.0356 \\
\hline
\end{tabular}


Table 2

System-GMM estimation for insider ownership equation

This table reports the regression results on firm performance based on the following regression specification

$$
y_{i t}=\alpha_{0 t}+\alpha_{1} x_{i t}+\boldsymbol{\alpha}_{2} \mathbf{C}_{\mathbf{i t}}+\alpha_{3} y_{i t-1}+u_{i}+\eta_{i t} .
$$

The dependent variable is insider ownership (IOWN), which is the logarithm of the percentage of the number of shares owned by insiders (directors and officers) divided by the total number of shares outstanding. Firm-specific effects are removed by first-differencing, while time dummies and intercept are included but not reported. There are two key explanatory variables and 11 control variables. The two key explanatory variables are lagged insider ownership (IOWN(-1)) and Tobin's Q. The control variables include gross cash flows (CF), firm size (FSIZE) and its square (FSIZE²), investment growth (GROWTH), hard capital intensity (HARD_C) and its square (HARD_C2), managerial risk aversion (MRA), two proxies for soft capital intensity (SOFT_C1 and SOFT_C2). To capture the effect of missing values, two dummy variables are also created for SOFT_C1 and SOFT_C2, which are referred to as SOFT_C1_DUM and SOFT_C2_DUM, respectively. The definition of these variables is described in Appendix A

The first four rows of Panel A report specification test statistics that are used to test for the appropriateness of the system-GMM model specification. The Sargan test of over identification restrictions and the differenced-Sargan test are used to check for the validity of the instruments used for system-GMM estimation. The former tests for the possibility of using too many instruments while the latter specifically tests for the validity of additional moment conditions used in the level equations. The next two tests detect the absence of first-order and second-order serial correlation in the first-differenced residuals in the above equation. If the error terms are not serially correlated, the first-differenced residuals should be negatively autocorrelated in the first order but not in the second order. The last row reports differenced-Sargan test results that compare the adjustment cost model with a fixed-effects model with serially correlated errors. Panel B reports the system-GMM estimates.

\begin{tabular}{lc}
\hline Number of firms: & 1,430 \\
Sample period: & $1991-2000$ \\
Instruments used: & $\mathrm{IOWN}^{*}{ }^{*}$ \\
& $\mathrm{p}$-value \\
\hline Panel A. Specification tests: & 0.406 \\
\hline Sargan test (for lagged levels dated t-4): & 0.224 \\
Differenced-Sargan test (for lagged first-differences dated t-3): & 0.000 \\
Test for first-order serial correlation: & 0.637 \\
Test for second-order serial correlation: & 0.517 \\
Differenced-Sargan test (for model comparison): &
\end{tabular}

Panel B. System-GMM estimates:

\begin{tabular}{lccc} 
Independent variables & Coefficient & Std. Error & p-value \\
\hline IOWN(-1) & $\mathbf{0 . 5 8 2 3}$ & $\mathbf{0 . 1 4 4 3}$ & $\mathbf{0 . 0 0 0}$ \\
$\boldsymbol{Q}$ & $\mathbf{- 0 . 1 8 7 7}$ & $\mathbf{0 . 1 3 1 1}$ & $\mathbf{0 . 1 5 2}$ \\
CF & 0.0083 & 0.0090 & 0.356 \\
FSIZE & -13.8148 & 7.6961 & 0.073 \\
FSIZE & -1.9848 & 1.1245 & 0.078 \\
GROWTH & -0.0338 & 0.0357 & 0.344 \\
HARD_C & 0.2766 & 0.2099 & 0.188 \\
HARD_C & -0.0019 & 0.0016 & 0.247 \\
MRA & 0.2898 & 0.6764 & 0.668 \\
SOFT_C1 & -0.1545 & 0.1119 & 0.168 \\
SOFT_C1_DUM & 17.0842 & 12.3085 & 0.165 \\
SOFT_C2 & 0.0637 & 0.1120 & 0.570 \\
SOFT_C2_DUM & 5.4401 & 25.1484 & 0.829 \\
\hline
\end{tabular}

*: The number " 4 " refers to the lag length of the latest instrument used in each cross section. In addition, two additional instruments are used. They are HARD_C and its square. 
Table 3

System-GMM estimation for corporate performance equation

This table reports the regression results on firm performance based on the following regression specification

$$
y_{i t}=\alpha_{0 t}+\alpha_{1} x_{i t}+\alpha_{2} x_{i t}^{2}+\boldsymbol{\alpha}_{3} \mathbf{C}_{\mathbf{i t}}+\alpha_{4} y_{i t-1}+u_{i}+\eta_{i t} .
$$

The dependent variable $(y)$ is Tobin's $\mathrm{Q}$, which is defined as the ratio of a firm's market value divided by the replacement value of its assets. Firm-specific effects $\left(u_{i}\right)$ are removed by first-differencing, while time dummies $\left(\alpha_{0 t}\right)$ and intercept are included but not reported. There are three main explanatory variables $\left(x_{i t}, x_{i t}{ }^{2}\right.$ and $\left.y_{i t-1}\right)$ and 11 control variables $\left(\mathrm{C}_{\mathrm{it}}\right)$. The two main explanatory variables are IOWN and its square. IOWN is the percentage of insider ownership. The set of control variables is the same as that used in Table 2. The definition of these variables is described in Appendix A

The first four rows of Panel A report specification test statistics that are used to test for the appropriateness of the system-GMM model specification. The last row reports differenced-Sargan test results that compare the adjustment cost model with a fixed-effects model with serially correlated errors. See Table 3 for the detailed descriptions of these five tests. Panel B reports the system-GMM estimates.

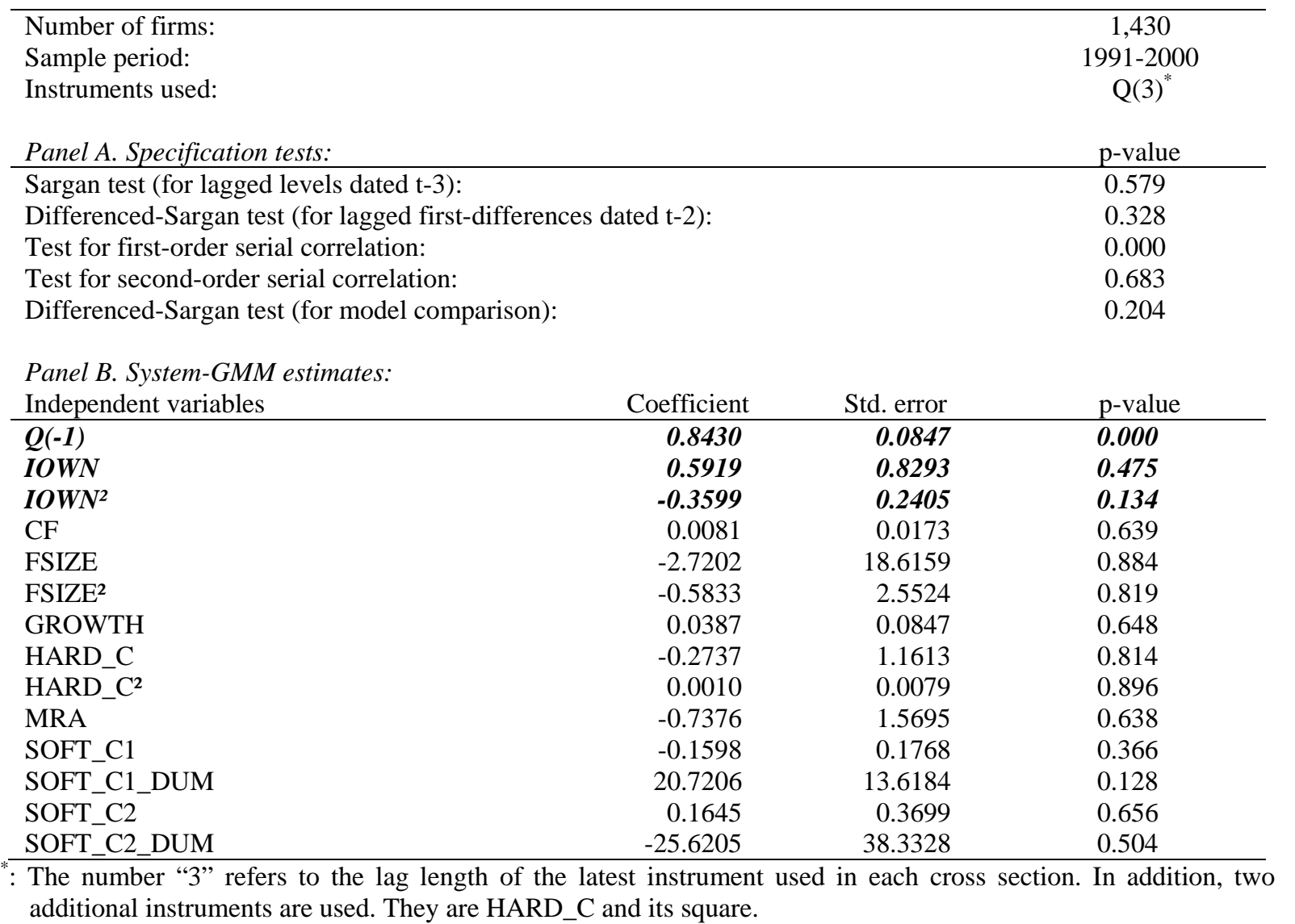


Table 4

Determinants of speed of adjustment for insider ownership

This table reports the regression results on firm performance based on the following regression specification:

$$
\begin{aligned}
y_{i t}= & \alpha_{1} x_{i t}+\boldsymbol{\alpha}_{2} \boldsymbol{C}_{i t}+\gamma_{0} y_{i t-1}+\gamma_{1}\left(\text { AMENITY }_{i t} \times y_{i t-1}\right)+\gamma_{2}\left(\text { INOWN }_{i t} \times y_{i t-1}\right)+\gamma_{3}\left(\text { NHOLDER }_{i t} \times y_{i t-1}\right) \\
& +\gamma_{5}\left(\text { TIMING }_{i t} \times y_{i t-1}\right)+\alpha_{4} u_{i}+\omega_{i t} .
\end{aligned}
$$

The dependent variable is insider ownership (IOWN). Firm-specific effects are removed by first-differencing, while time dummies and intercept are included in the regression but not reported. There are one key explanatory variable, 11 control variables and four interaction variables with lagged insider ownership (IOWN(-1)). The explanatory variable is Tobin's Q. The set of control variables is the same as that used in Table 2 . Four interaction terms, which are the four adjustment-cost determinants multiplied by lagged insider ownership (i.e., AMENITY $\times$ IOWN(-1), INOWN $\times$ IOWN(-1), NHOLDER $\times \operatorname{IOWN}(-1)$ and TIMING $\times \operatorname{IOWN}(-1)$ ) are included. The definition of these variables is described in Appendix A. Panel A reports specification test statistics that are used to test for the appropriateness of the system-GMM model specification. See Table 2 for the detailed descriptions of these four

\begin{tabular}{|c|c|c|c|}
\hline \multicolumn{3}{|l|}{ Number of firms: } & 1,430 \\
\hline \multicolumn{3}{|l|}{ Sample period: } & $1991-2000$ \\
\hline \multicolumn{3}{|l|}{ Instruments used: } & $\operatorname{IOWN}(4)^{*}$ \\
\hline \multicolumn{3}{|l|}{ Panel A. Specification tests: } & p-value \\
\hline \multicolumn{3}{|c|}{ Sargan test (for lagged levels dated t-4): } & 0.801 \\
\hline \multicolumn{3}{|c|}{ Differenced-Sargan test (for lagged first-differences dated t-3): } & 0.700 \\
\hline \multicolumn{3}{|c|}{ Test for first-order serial correlation: } & 0.000 \\
\hline \multicolumn{3}{|c|}{ Test for second-order serial correlation: } & 0.748 \\
\hline \multicolumn{4}{|c|}{ Panel B. System-GMM estimates: } \\
\hline Independent variables & Coefficient & Std. error & p-value \\
\hline IOWN(-1) & 1.1166 & 0.2055 & 0.000 \\
\hline $\mathrm{Q}$ & -0.1672 & 0.1599 & 0.296 \\
\hline $\mathrm{CF}$ & -0.0009 & 0.0105 & 0.935 \\
\hline FSIZE & -0.3156 & 5.5982 & 0.955 \\
\hline FSIZE $^{2}$ & -0.0093 & 0.8043 & 0.991 \\
\hline GROWTH & -0.0424 & 0.0461 & 0.357 \\
\hline HARD_C & 0.1964 & 0.2867 & 0.493 \\
\hline HARD_C ${ }^{2}$ & -0.0011 & 0.0022 & 0.609 \\
\hline MRA & 1.0072 & 0.9572 & 0.293 \\
\hline SOFT_C1 & -0.2569 & 0.1233 & 0.037 \\
\hline SOFT_C1_DUM & 29.4607 & 15.1696 & 0.052 \\
\hline SOFT_C2 & 0.1514 & 0.1289 & 0.240 \\
\hline SOFT_C2_DUM & -10.1701 & 28.4649 & 0.721 \\
\hline AMENITY $\times I O W N(-1)$ & -0.0285 & 0.0181 & 0.117 \\
\hline$I N O W N \times I O W N(-1)$ & -0.0014 & 0.0016 & 0.375 \\
\hline NHOLDER $\times$ IOWN(-1) & 0.0010 & 0.0003 & 0.000 \\
\hline TIMING $\times$ IOWN(-1) & -0.0433 & 0.0107 & 0.000 \\
\hline
\end{tabular}
tests. Panel B reports the system-GMM estimates.

*: The number "4" refers to the lag length of the latest instrument used in each cross section. In addition, eight additional instruments are used. They are DA×Q(-1), FSIZE, FSIZE², HARD_C, HARD_C 2 , MS $\times Q(-1), Q \times Q(-1)$, and STDDEV $\times \mathrm{Q}(-1)$. 
Table 5

Determinants of the speed of adjustment for corporate performance

This table reports the regression results on firm performance based on the following regression specification:

$$
\begin{aligned}
y_{i t}= & \alpha_{1} x_{i t}+\alpha_{2} x_{i t}^{2}+\alpha_{3} C_{i t}+\gamma_{0} y_{i t-1}+\gamma_{1}\left(D A_{i t} \times y_{i t-1}\right)+\gamma_{2}\left(M S_{i t} \times y_{i t-1}\right)+\gamma_{3}\left(Q_{i t} \times y_{i t-1}\right) \\
& +\gamma_{5}\left(S C_{i t} \times y_{i t-1}\right)+\gamma_{7}\left(S T D D E V_{i t} \times y_{i t-1}\right)+\alpha_{4} u_{i}+\omega_{i t} .
\end{aligned}
$$

The dependent variable is Tobin's Q (Q). Firm-specific effects are removed by first-differencing, while time dummies and intercept are included in the regression but not reported. There are two key explanatory variable, 11 control variables and five interaction variables with lagged $\mathrm{Q}(\mathrm{Q}(-1))$. The explanatory variables are insider ownership (IOWN) and its square. The set of control variables is the same as that used in Table 2. Five adjustmentcost determinants multiplied by lagged $\mathrm{Q}$ (i.e., $\mathrm{DA} \times \mathrm{Q}(-1), \mathrm{MS} \times \mathrm{Q}(-1), \mathrm{Q} \times \mathrm{Q}(-1), \mathrm{SC} \times \mathrm{Q}(-1)$, and $\mathrm{STDDEV} \times \mathrm{Q}(-1)$ ) are included. The definition of these variables is described in Appendix A. Panel A reports specification test statistics that are used to test for the appropriateness of the system-GMM model specification. See Table 2 for the

\begin{tabular}{|c|c|c|c|}
\hline \multicolumn{3}{|l|}{$\begin{array}{l}\text { Number of firms: } \\
\text { Sample period: } \\
\text { Instruments used: }\end{array}$} & $\begin{array}{c}1,430 \\
1991-2000 \\
Q(2)^{*}\end{array}$ \\
\hline \multicolumn{3}{|l|}{ Panel A. Specification tests: } & p-value \\
\hline \multirow{4}{*}{\multicolumn{3}{|c|}{$\begin{array}{l}\text { Sargan test (for lagged levels dated t-2): } \\
\text { Differenced-Sargan test (for lagged first-differences dated t-1): } \\
\text { Test for first-order serial correlation: } \\
\text { Test for second-order serial correlation: }\end{array}$}} & 0.331 \\
\hline & & & 0.298 \\
\hline & & & 0.000 \\
\hline & & & 0.564 \\
\hline \multicolumn{4}{|l|}{ Panel B. System-GMM estimates: } \\
\hline $\mathrm{Q}(-1)$ & 1.3083 & 1.1496 & 0.255 \\
\hline IOWN & 0.7107 & 0.8310 & 0.392 \\
\hline $\mathrm{IOWN}^{2}$ & -0.2472 & 0.2282 & 0.279 \\
\hline $\mathrm{CF}$ & -0.0027 & 0.0044 & 0.540 \\
\hline FSIZE & 10.5445 & 14.2039 & 0.458 \\
\hline FSIZE $^{2}$ & 1.4522 & 2.0494 & 0.479 \\
\hline GROWTH & -0.0145 & 0.0189 & 0.444 \\
\hline HARD_C & -0.9350 & 0.9986 & 0.349 \\
\hline HARD_C ${ }^{2}$ & 0.0079 & 0.0083 & 0.344 \\
\hline MRA & -0.0910 & 0.1276 & 0.476 \\
\hline SOFT_C1 & -0.1529 & 0.1380 & 0.268 \\
\hline SOFT_C1_DUM & 15.8421 & 13.9773 & 0.257 \\
\hline SOFT_C2 & 0.2823 & 0.1837 & 0.124 \\
\hline SOFT_C2_DUM & -39.7005 & 32.1961 & 0.218 \\
\hline$D A \times \bar{Q}(-\overline{1})$ & -0.1358 & 0.0289 & 0.000 \\
\hline$M S \times Q(-1)$ & -0.0012 & 0.0067 & 0.858 \\
\hline$Q \times Q(-1)$ & 0.6078 & 12.5730 & 0.961 \\
\hline$S C \times Q(-1)$ & 0.2748 & 0.2129 & 0.197 \\
\hline$S T D D E V \times Q(-1)$ & -0.0671 & 0.0373 & 0.072 \\
\hline
\end{tabular}
detailed descriptions of these four tests. Panel B reports the system-GMM estimates.

*: The number " 2 " refers to the lag length of the latest instrument used in each cross section. In addition, nine additional instruments are used. They are CF, DA $\times Q(-1)$, FSIZE, GROWTH, HARD_C, MRA, SOFT_C1, SOFT_C2, and STDDEV $\times Q(-1)$. 